\title{
LA-4723-MS
}

\section{Proposal for an}

Intense Steady-State Neutron Source 
This report was prepared as an account of work sponsored by the United States Government. Neither the United States nor the United States Atomic Energy Commission, nor any of their employees, nor any of their contractors, subconiractors, or their employees, makes any warranty, express or implied, or assumes any legal liability or responsibility for the accuracy, completeness or usefulness of any information, apparatus, product or process disclosed, or represents that its use would not infringe privately owned rights.

This repori, like other special-purpose documents in the LA. . .MS series, has not been reviewed or verified for accuracy in the interest of prompt distribution.

Printed in the United States of America. Availablt from National Technical Information Service

U. S. Department of Commerce

5285 Port Royal Road

Springfield, Virginia $2215 \hat{i}$

Price: Printed Copy \$3.00; Microfiche $\$ 0.95$ 
LA.4723-MS

UC-80

ISSUED: July 197!

solantific laboratory

of the University of Californic

LOS ALAMOS, NEW MEXICO 87544

1

\section{Proposal for an}

\section{Intense Steady-State Neutron Source}

by

L. D. P. King

This report was prepared as an account of work sponsored by the United States Governinent. Nelther the United States nor the United States Atomic Energy Comminaion, nor any of their employees, nor any of their contractors, subcontractors, or their omployees, mikes any warrenty, expreas or implied, or besumes any

lefal liability of responsiblity for the accuracy, com-

pleteness or usefulness of any informbion, apparatua,

product or process disclosed, or represents that its use

would not infringe privstely ciwned rights. 


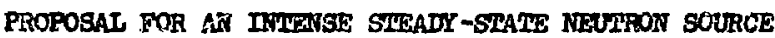

by

I. D. P. KIng

\section{ABSIRACI}

The Rinetic Intense Neutron Generator (KMra) reactor is an advanced concept which prowises to provide a substantial breakthrough in existing steady-state neutron Fluxea.

The use of a rapidly moving aqueoris liquid ruel core remores present steady-state reactor flux ifmitations $B$ ince no latermal heat exchanger is required. The vide renge in urantim fuel concentrations which are permisstble in such a ssatem ensbles one firr the firat time to optimize both the annuiar fuel region and control flux trap to gdve the hleliegt pexformence index or ratio of thermal fux to reactor poser.

A conservative 25-1N power leve' is proposed for the reactor at Los Alamos. such a power level does st stralin the existing woter supply and requirea essenttally no new technology. Fhe rmal neutron rlox levels are estimated to be second to none at thls porer level.

The full flux potestial for this concept is not known and wijl require research and developmets. A 25-14 reactor can serve as a test bed for further studies in which ruel velocities and core transit temperature rise are increased for short times. presented.

A description of the xing reactor concept and its dynamic test is

The need for and fmportance of fully exploitling the unique diagnostic properties of neutrons by lnereasing existing flux Intensities is well inown. Caly a few specifle examples of IASI interest are therefore given in the Aplendix.

\section{TFROTRCITION}

It is vell known that reutrons joseess unique qualities for study Ing the sirexture of matter, the motion of atcess, the production of new atomic spectes, and for the detection or aimute traces of materisis.

The need tor wore Intense neutron sources for edvances in varloug flelds of gclence and technology has been vell described. 1,2

Substantial progress has been made in the past decade in the techniques for using neutrons to help satisf thess needs. During this tire, however, I1ttle progress has been made in the desien and construction of more intense steady-state neutron sources.
An optimization of existing technology was achieved by the Oak RIdge BFIR design ${ }^{3}$ initiated in 1958. The $5 \times 10^{15}$ thereal neutron flux achieved In 1966 in this reactor has recelved little challenge. Only sllyht improvements appear posstble in this tyre of core design, and then by rather herole wethods. 4,5

A new approsch for producing a wore Intense steady-btate neutron source was used by the Canadians In their proposed Intenge Neutron Generator (ING).2,6 This device was based on the spallation rather than fisston process. Thermal Iivxes of $10^{16}$ ts: $13^{.17}$ neutrons $/ \mathrm{cm}^{2} / \mathrm{sec}$ vere predicted. The high cost of butlding such a device which required very largo 
currents of high-energy protong trapingling on a heavy element terget led to the abandoment of this proposel.

Further Increase in the neutron five from steady-gitate fisioion reactors using solld fuel elements is Ifmited by the bagic problem or heat extraction fron the core. A limit has been reached in the porer that can be extranted from such frel elewents becauge thermal and vibrational otresses have approached the strength of materials.

A new concept for a flssion reactor core and mode of operation developed at IOB Alsmos Sctentiflc Laboratory promises to remove not only the core heat extraction limitation but w1ll also permit an opt1mization of the performance Index which is a mosure of the maximum thermal neutron slux to the total reactor power. This new destgen concept is known as the KinetIc Intense Neutron Generator (KTHG) reastor.

The use of a rapialy moring liquid fuel in the core eliminates the need for an Intornal hest exchanger because the heat capacity of the fusl itself can be sufficient to remove the flssion energy released in the core. The use of an aqueous fuel such as uranyl sulfate which has a high solubility (> $3 \mathrm{M}$ ) for uranium provides an advquate raage in reactivity so that the theoretically optimun peak Iux geometry can be chosen for the first time.

Calculations 7,8 have shown that peak thermal furces cer be achieved in a centrel water flux trap Island only if the fuel concentration can be raried sufficiently so the thickneas of the annular fuel region as vell as the radius of the water 1siand can be adjusted to optimn dimensions. These sonditions as well as high totel power requirements appear to be by the KnNG reactor design, which has the potential for providing steady-state neutron fluses one or two orders of magnitude above those presentiy avallable.

Testing of the neutronic and hydraulic properties of this woving core concept is now in progress at Ios Alanos. Suese static and ónamic critical tests, called the Kinglet experiments, are deacribed below.

\section{KTHG REACTOR PROPOSAL FOR IOS ALANOS}

The highest flux potential of this type of reactor w11l require oome reseaxch and develogment.
Even when operating st the highest poesible performance index, the ultimate attainable flux witl require a large total power output.

It is therefore proposed that only a 25 ty kntis reactor be conotrucied at IOS Alamos. Inls modest power level is chosen for a number of reasons.

1. cooling requirements do not strain existing IOB Alamos water supplies.

2. No new technical problems appear to extat for steady-otate operation at this power level. operating temperatures $<100^{\circ} \mathrm{C}$ and ruel velocities $<60 \mathrm{ft} / \mathrm{sec}$, adequate for this pover dissipation, are known not to ceuse apprectable corrosion, oroston, or fuel otability problems.

3. Calculations indicate that, even at this relatively low power lovel, the world's highest steady-state fluxes should be obtalned.

i. The former UHUREx resctor fecility is avallable. This bullaing with its auxiliary equipwent was desiened for an experinentel reactor and therefore offers numerous features ideally suited for a KIIV reactor, such as a complete secondary contalment shell and remote handling equipant. It appears that with a fex wodiflcations following the removal of the UHurax core a 25* kntG reactor could be installed at a substantial saving over building ouch a reactor from scratch.

5. A 25 Kaw KING reactor at Ios Alamos w1II aot oply supply very adyanced neutron research capabilIties to replace the existing owega West facility but can also be usad as the test bed to demonstrate that this type of reactor has the capebility for a substantial additional increase in flux.

The Kinglet experiments now in progress at IOs Alamos will denonstrate the nuclear propertits of such a woving core system under realistic power and operating conditions.

\section{KTIO REACTOR DESICN COHCEPT}

As Indicated above, the breakthrough in steadsstate thermal fluxes which appears possible with this new core design and mode of reactor operation Is due to the elimination of the normal type of core heat exchanger.

The use of twel elementio in the core has not orly linited speciflc power and bence neutron intensities hut has also provented designing the core to 
maximize the neutrons per unit of power. This latter consideration becomes very important when total power outyut, may be the cost limiting consideration for the production of a very Intenge steady obtate neutron source.

Wost, if not all, previous designs for steacystate high flut reactors have been otrongly influenced by core develogpents aimed at the production of useful power. The kTrG reactor desifm was developed solely for the production of neutrons and has ifmored other design concepts and thus could bypass previous technical limitations.

The most intense neuriron sources have in the past aivays been associeted with fagt burst reactors. 10 Th1s is due to the fact that this type or reactor does not depend solely on the heat extraction by a conventional heat exchanger but has made use of the heat capacity of the core materials to aisorb the almost Instantaneous fisston energy release.

The KIIG reactor design has made full use of this advantage of burst reactors. A raplaly moring IIquid fuel has every element of fuel subjected to a burst during core transit but because of cont1mous core replecement results in a steady-state neutron Plux.

Figure 1 illustrates schematically the hasic and auxillery KIrG reactor components excilusive of shielaing and reactivity shim. The Ilquidi fuel, such as uranyl oulfate, is pumped up and through the anmular core tuel region (IA-IB) where it is beated by flssion energy during Its flow through the core. Fuel emerging from the top of the core Lupects against a fuel deflector (2) which disperses the fuel radially outwards into a contatsment ressel (3). From here the ruel flows by momentum and gravity into an annular fuel plenum which leads to the exterad ruel circulation prups and main heat exchangers (5). Solution leaving the heat exchangers is returned to the core region through pipes (6).

Radiolyt1c gas is produced in the solution during core transit. To arold possible Ignition of the radiolytic gas forwed, an inert gas is elrculated through the contrainment vessel (3). This gas flows in a closed system down the anmular duct $(7-8)$

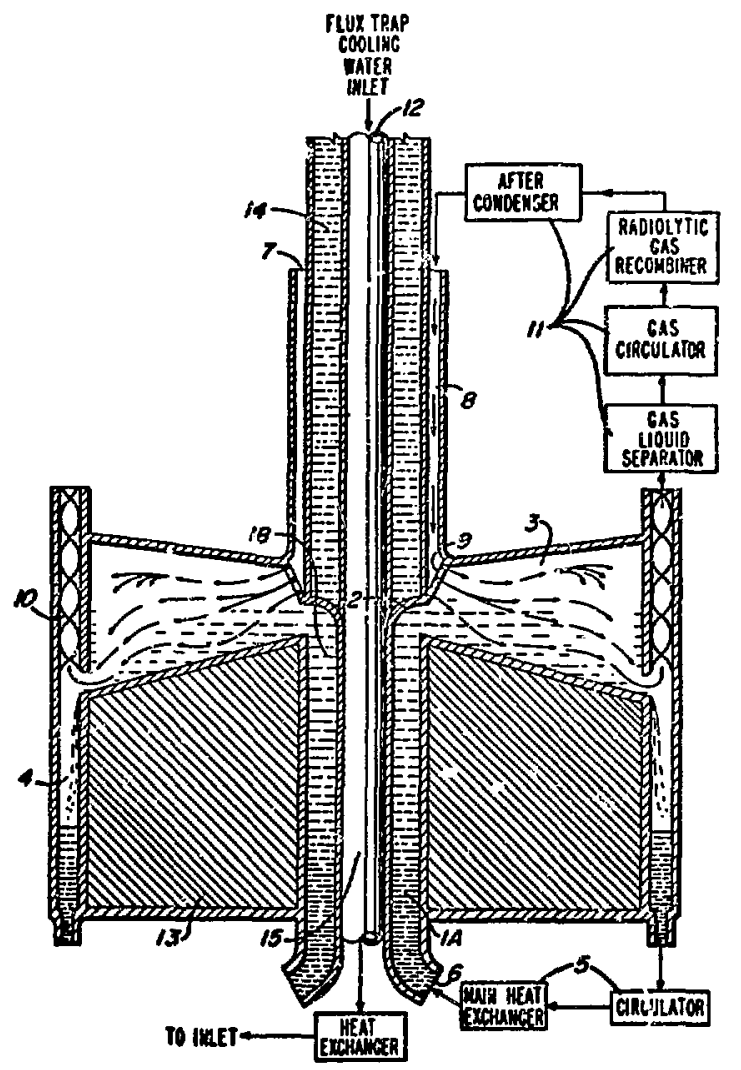

F1g, 1. Schemat1c KUIG reactor with some of the auxiliary equipment.

and through apertures (9) where it mixes with the efecting fuel and entraired radiolyt1c gas. The contalment vessel (3) serres as the first stage of a IIquid-gas separation system which Inclucies a Iiquid condensation region (10) followed by other components labeled (11) in the flgure.

Water enters at (12) through the anmular shield plug (14) to supply the neutron moderation and coolIng for samples placed in the central fur trap region (15). cooling channels, reactivity shim control, and structural detalls are not shown in the schematic beryllium roflector region (13).

Most of the baglc components of this design nied be only scaled up to make use of technology proved in more than 20 years of successful operation of the IOS Alamos water Boller reactor, 17 Inere is one inportant new feature, horever--the repid motion 
of the fuel through the core. This bastc change in mode of operation permits an astounding increase in the energy dissipation capabilifies in the core. A new interesting muclear feature also appears for this type of operation in that for rapid fuel motion the reactor 111 no longer operate with normal deleyed neutrons because of the short core residence time. Heflector neutrona, however, will, supgly a constant large source of very shcrt-term delay neutrons in alreat proportion to the power lerel of operativa.

corrosion and high-temperature fuel instabllity problems which stopped the Oak Ridge Bomogeneous Reactor Project ${ }^{12}$ do not exist in the knig reactor concept for two principal reasons.

1. The purpose of the XIrG reactor 18 the production of neutrons and not the production of useful power so that fuel temperatures can be $10 \mathrm{w}$ ered from a 250 to $275^{\circ} \mathrm{C}$ range to less than $100^{\circ} \mathrm{C}$. zirconiun, for example, which is an excellent core rabrication material, is very comosion resistant at $200^{\circ} \mathrm{C}$ in sulfurlc acta concentrations up to $75 \% .^{13}$ The cause for the enhanced zircontim corrosion in the presence of radiation, which was observed in the oak Ridge work, is now understood 14

2. Substantial advances have been made in matertals technology in the past decade for containing urangl sulfate frel. Feactor couponents such as heat exchangers, for excample, can now be rabricated as cheaply of titaniun as of stainless steel. 15 New highly corrosion resistant zirconium-tantalum alloys have been developed in Russia. I6 corpenter stainless steel \#200b-3 with superior sulfuric acid corrosion resiatant properties is now readily avallable and is well suited to other than core IING reactor components.

The simplicity of the ICHG reactor core regton will permit not only optimizing thermal neutrons in the central 1slanis but also fast neutrons. Fy removing the water from the central 1sland and insertIng a thin anmiler neutron comrerter existing fast neutrons will be enhanced and thermals removed in the island cavity. The neutron converter yould consist of HFIR type ruel sandwiches $w$ ith the required annular coolant water channels.

The sinflicity of the KIVG reactor core region will rurthermore make it relativeiy easy to tegt and replace advanced core materlals ${ }^{17}$ that are subject to damage by fission products or by intense radiation. This capability will be useful in any program ained at testing the full potential of the KTFG reactior concept. Oak Ridge, for example, has found It necessary to replace the Inner beryllium reflec. tor sleeve after a fast neution avt of about $10^{22}$ In the HPIR.

Steady-state fuel energy density limitations are avolded by adjusting the fuel exposure $t$ ime during core trangit and by the large total externai fuel Inventory. The uranyl sulfate fuel has been successfilly exposed to very bigh Intensities in a pulaec operation in the Kinetic Water Boller Experiments (KEAB). 18

The phrical properties of aqueous sulfate fuels are well ksown from early IASC vork and detalled studles for the Cak Ridge Homogeneous Reactor Project. 19

Extersive work has been carrled out on the radiation chemistry of aqueous reactor fuels. 20 Potential ITNG reactor fuel stabllity problens have been examined at Ios Alamos. 21 This work indicates that at the proposed 25-M operation no problems should be encountered.

A large effort at Oak Ridge also went Into the hign-teirperature chemistry of urangl sulfate fuels. 22 Although not directly applicable because of the much lower temperatures that w111 be used on the SDTG reactor, this work illustrates the laxge amount of knowledge aratlable for thls type of fuel.

Recent work ait tos Alamos ${ }^{23}$ has investigated the hydraulic effects in a kWING reactor. Ihls work Is important since the actuel fuel residence $t$ ime Is a function of the radial fuel velocity profile. The results of this work are now being included in a calculational study ${ }^{24}$ of the overall hydraulicneutronic operating behavior of a kTTG reactor.

Optimm core aimensions for the highest performance index require o flux trap diameter of about $10 \mathrm{~cm}$ and an anmilar fuel thtekness of about $3 \mathrm{~cm}$. This requines a fuel loading of aboxi: $200 \mathrm{~g}$ 235 V/liter which Bives an $\mathrm{H} / \mathrm{U}=111$.

The power equation for the KDIG reactor is

$$
P \text { watts = HAvOP, }
$$


where $\mathrm{H}=$ heat capacity of the fuel (watts$\left.\sec /{ }^{\circ} c-\cos 3\right)$,

$A=$ cross-sectional area of the thel annulus $\left(\mathrm{cm}^{2}\right)$,

$v=$ fuel velocity through the core $(\mathrm{cm} / \mathrm{sec})$,

$\Delta r=$ fuel temperature rise during core transit ("c).

For a given ruel solution, the core geometry $H^{\prime} A$ is a constant. The power output is then solely dependent on the product of fuel velocity and temporature rise during core transit.

Since the heat capecity of the uranyl sulfate fuel for the concentrations of intereat ( $<0.9 \mathrm{H}$ ) is essentially that of water and the fuel area in en optimm flix core is aboit $123 \mathrm{~cm}^{2}$, the product $v \cdot \Delta T=4.85 \times 10^{4}$ for a power of $25 \mathrm{MH}$.

One crotously has a brad range of cholces of velocity or temperature rise. If the $\Delta r$ is chosen as $30^{\circ} \mathrm{C}$, for example, the velocity w1ll be 1615 $\mathrm{cm} / \mathrm{sec}$ or $53 \mathrm{ft} / \mathrm{sec}$.

The ilost desirakle KING reactor startup and operating procedures $x$ ill. be established in the Kinglet experiments. It now anpesrs that the use of an annular shim for reactivity control simplifies operatira procedures because the hydraulic parameters can then be established for startup prior $t$ : the amparance of any nuclear effects.

simllarly, the Kinglet expertinents $w 111$ be used to study ruel deflect1ol. gecmet-ipies at the core exit.

Work on the kMrg reactor concept has been summarized in laboratory reports ${ }^{25}$ eince 1ts inception in 1967 as well as in the Iiterature. 26

\section{KMTGLET EXIPER IMERTIS}

A new and interesting feature of the knitG reactor concept mentioned abore is the precise nuclear behavior to be expected in a amali Ifquid core when operating only on reflector neutrons rather than the normal delayed neutrons.

It therefore seemed advisable to carry out a series of static ans dynamic criticel experiments to test the basic sutron propertien of a rapidly moving liquid fuel core under conditions that would be realistic for a high-fiux facility.

The Kinglet Lomamic Criticel bxperiments are now being carried out at Pajarito site in IOB Alamos as the basic feasibility test of the concegt. Because the purpose of these experiments is to tesi the nuclear properties of the core, much of the auxiliary equipment required for an actual reactor can be elfminated or modified. Floure ?, a verticel section through the Kinglet device, therefore does not jesemble in a number of ways a KONG bigh-flux neutron device.

The besic cauponents of the Kinglet assembly shown in Fig. 2 are an overall contalment shell, an annular fuel reservoir, a tuel clrculetion pump, a zirconfum core tive, a fuel deflector above the core regica, a berylliva reflector, and os shim polson sleeve with ictuator. Auxiliary couponente also shown are a iieans for venting the moin contalnment vessel, a fuel saruling and liquid addition pipe, a fuel level indicator, and a plpe leading to an outside fuel storage tank.

Numerous costly and large components required In a full-scale reactor which could be elininated in the Kinglet experiments are gas-liquid entreinment separator, radjolytic gas diluent and recombluation system, reiluctor coolant system, heat exchanger, experimental irradiation facility and flux trap, and radiation shilelaing.

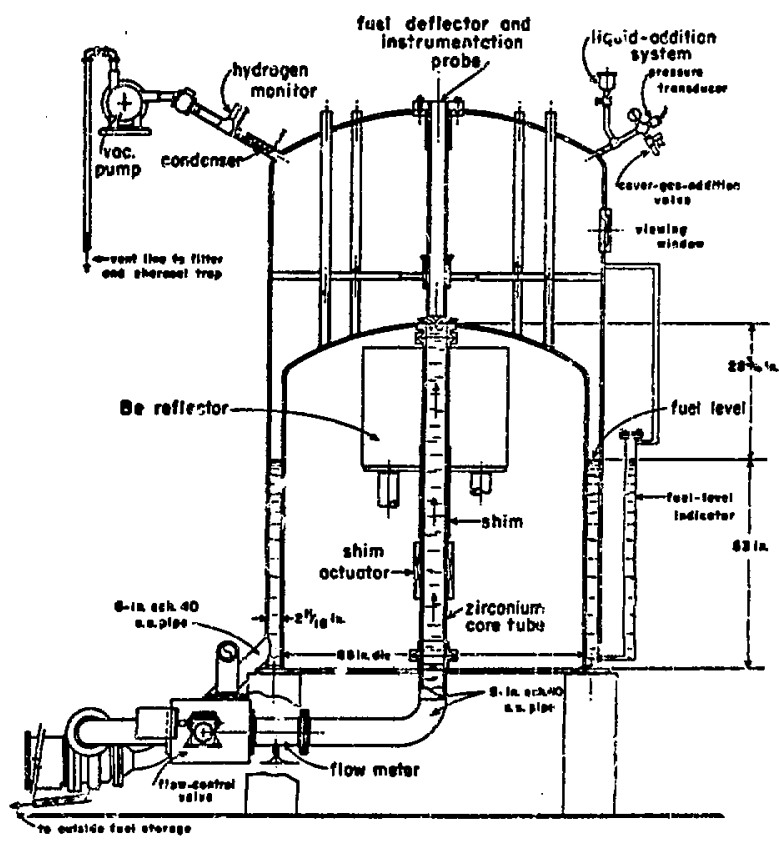

F18. 2. Dymamic Test Facllity -"Kinglet", 
These corponents could be eliminated in the Kinglet assembly due to the planned mole of operacion which covid test nuclear properties without 1008 pertods of steady-btate operation. Each rwn is initialiy Iinited to about, $40 \mathrm{if}-\mathrm{sec}$ energy release to fall within present operatinis procedures for exticel assemblies at ?ajarito site. Thts type of energy limitation permits each run to be carried out r motely without a ahield or heat exchanger if sufPlclere time to allowed betieen runs. Raulolytic gages released during such a run have adequate dilution In the large containment shell volume above the fiel deflector. For htgh-power tegt runs, a flattopped pulse cperation will ". a used rither than steady-state operation, 1 .e., power is brought up raptaly, leveled off, and stopped rapidily so as not to exceed the $40 \mathrm{NW}-$-8ec energ releage limitation per run. Luring the flat-tor persod, the nuclear staliily will be determined. Pad Lolytic gas is vented between ror.s following decay.

Ithe simplicity of the core and elimination of much of the auxi.jary equipment has permitted reallatic sesting of tho concept in a relatively simple setup.

Eydreulic properties of the grsten can be studied independent?y of neutronic effects since with the shim in the "In" position the system is held substantially suberttical. A precalibration of the worth of the shim as a function of position: permits a choice of tre $\Delta P$ that the fuel will be subjected to during core transit and is independent of the fuel velocity. An increase in velocity for ary chosen $\alpha$ increases the poser output in direct proportion as indicated in the power equation mentioned in section III above. Some nonlinearlty w11l appear in these simple relations when specitlic power levels are such as to form appreclable amounts of radiciytic gas.

Internal memoranda and progress reports 27 on the Kinglat experiments and other related work have been sumarized in the querterly status reports 25

A safety evaluetion report ${ }^{28}$ has been prepared and the folloring table ists the proposed operating conditions for the inglet experiments.

\section{TARE}

\begin{tabular}{|c|c|}
\hline Narimm power & $4000 \mathrm{~kg}$ \\
\hline Speciflc power (max) & $700 \mathrm{kw} /$ liter \\
\hline $\begin{array}{l}\text { opereting tims per test at } \\
\text { full power }\end{array}$ & $10 \mathrm{sec}$ \\
\hline Total elssione per test & $2.24 \times 10^{18}$ \\
\hline $\begin{array}{l}\text { N-2 flssion 1fintationo/10-sec } \\
\text { burst }\end{array}$ & $1.36 \times 10^{18}(41 \mathrm{kH}-\mathrm{sec})$ \\
\hline Core volume (cold critical) & $\sim 8.0$ Iiters \\
\hline cote operating volume & 9.0 Ilters \\
\hline Operating core helght (max) & n.1 cm \\
\hline Core cross-gectionel area & $226.6 \mathrm{~cm}^{2}$ \\
\hline Fuel inlet teuperature & 20 to $50^{\circ} \mathrm{C}$ \\
\hline Fuel cutlet temperature & 20 to $50^{\circ} \mathrm{C}$ \\
\hline $\begin{array}{l}\text { Fuel ar (at max fuel } \\
\text { velocity) }\end{array}$ & $\approx 10^{\circ} \mathrm{c}$ \\
\hline Core velocity (max) & $\begin{array}{l}688 \mathrm{~cm} / \mathrm{sec} \\
(\sim 22.5 \mathrm{ft} / \mathrm{sec})\end{array}$ \\
\hline Fuel purging rate (max) & $\begin{array}{l}87 \text { liters } / \mathrm{sec} \\
(1250 \mathrm{gel} / \mathrm{min})\end{array}$ \\
\hline Fuel inventory (max) & 600 l1ters \\
\hline Uranium Irrentory (max) & $51.6 \mathrm{kB}^{235}$ \\
\hline Fuel storage & $\begin{array}{l}200 \text { ft of } 6-1 n .- \\
\text { dian pipe }\end{array}$ \\
\hline $\begin{array}{l}\text { Rediolytic gas production } \\
\text { (max) SIP }\end{array}$ & 17 Iiters $\mathrm{H}_{2}-\mathrm{O}_{2} / \mathrm{sac}$ \\
\hline core reaidence tir: & 105 insec \\
\hline Energy deposition per pass & 44 ks-sec/I1ter \\
\hline
\end{tabular}

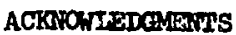

The autbor is indebted to G. A. cowan, D. C. Hoffman, and D. A. Carrett ror aupplying portlons of the material in the Appendix.

\section{RBFFRFATCBS}

1. Robert M. Brugger, "We Keed More Intsnse TheimeI Neutron Bearns, Fluysics Thdey 21, 23-30 (December 1968).

2. Seminar on Intense Veutron Sources (TID-45t0) Cavi-660925, Sauta Fe, New Mexico, September 19-23, 1965.

3. 'HIgh Flux Isotope Reactor Preliminary Design Stuty, "Oak RIage NetLonal Iaboratory Report (T) 59-2-65 (Narch 1959). (Al80 reference 2 above.)

4. J. I. Crandal1, "ihe Savannah RIver High Flux Demonotration," Savannah River Iaboratory Report IP-999 (TID-4500) (June 1965).

5. M. D. Donne, J. Kallfelz, and M. Muçhle, "sose Apsects of the Fensiblity of a 1016 Flux Reactor," 4x-579, Kernforschungszentrum. Karlsruhe (June 2967 ). 
6. "The AECL Syuposium on the Generation of Intense Neutron Fluxes, "AECL-2lT, Chalk River, Outario, Canods, Aprtl 22-23, 1965. (see reference 2 above.)

7. S. M. Felnberg, "HIgh Flux Stationary Besearch Reactors and Thetr outlook, "IAF-1693, Kurchatov Inst1tute of Atanic Energy, Moscow (1968). (see also IOs Alamos Seientific Laburatory Translation IA-4399-IR.)

8. Felix T. Adler, "Flux Optimization for a KIJG Reactior," Ios Alamos Scientiflc Laboratory Report LA-4722 (JuIy 1971).

9. 'Ulira High Temperature Reactior Experiment (UHREx) Fac1lity Description and Safety Analysis Report." IOs Alamos scientific Iaboratoxy Report IA-3556, Rev. (IID-4500) (February 1967).

10. "Fast Burst Reactors," CONF-\$90102, AEC 5ymposium sertes 15, Albuquerque, New Nexico, January 28-30, 1969. (see also reference 2 above.)

11. M. E. Bunker, "Status Report on the Water Bofler Reactor," IOS Alamos scientiflc Iaborztory Report IA-2854 (February 1963).

12. P. N. Heubenre 1ch, "Two Years of HRB-2 Operation," Muclear sclence and Eugineering 8 , $467-479(1960)$.

13. B. G. Parferw et al." "Corrosion of zirconium and Z1recnium Alloys," Atomizdat Noskva, p. 152 (1967).

14. B. Cox et el., "The oxidation and corrosion of Zirconium and Its Alloys, VI. The rechaniom of the Fission Fragment Induced Corrosion of 2ircaloy 2, Journal of the Blectrochemical society 108, 129-133 (February 1.961).

15. Mitanium Design Data Book for Chemical Processor, Titanium Netels Corp. of America, 233 Broadway, New York. Nes York.

D. Schlain, "Corrosion Properties of Titanium and Its Alioys," Bureau of Mines Bullet in 619 (1964).

16. V. V. Andreeva et al., "New Comogion Fee1stant Zirconium-Iantelum AIIOys," Bivlleten Tekhnillo-Ekonomicheshol Informats11 20, 14-16 (1967). (See also IOS Alamos Scientiflc Laboratory Transiation IA-4413-MR.)

27. H. Bohn1, "The Comosion Resistance of Severel Rare ktals in Dilute sulfurie Acid solutions vith Particurar Emphesis on N1obium and Tantalum, "Schretzer Archtr, Hov. $196 \%$.

18. M. S. Dunenfeld and R. K. Stitt, "stmmary Revlew of the Kinetic Bxperiments on Water Bollers," MAA-SR-TOBT (February 1963).

19. I. Felmholz and G. Friedionder, "Fursical Propertles of Uranyl sulfate solutions," IOS Alawos scient ifle Iaboratory Report IAMS-30 (December 1943).
M. K. Barnett et al.," "The Density, V16cosity and Surface Tenston of Iight and Heavy Water solutions of Uranyl sulfate at Temperatures to $250^{\circ} \mathrm{C}$," Mound Leboratory Report MIM-1021 (Deceruber 1954).

2C. J. W. Boyle ei al., "The Radiation Chemistry of Aqueous Reactor solutions. Pt. I. Radiation-Induced Decoupos It Ion," TID-2008, Resctor Sclence and Technology, VoI. 3, \#-1 (Aarch 1953). M. D. Silverman et al., "The Decompositior of Peroxide in Agueous Horiogeneous Reactor syetens," Pt. II, TID-2010, Reactor Science and Technology, vol. 3, \#3 (September 1953).

21. B. J. Thamer, IOs Alamos Sciantiflc Internal Progress Reports.

22. J. A. Iane et al., Pluld Fuel Reactors, Addison-Wesley Publishing Co., Reading, Kass . (June 1958).

23. Fellx T. Adler, "Hydralic Effecte in Clrculating Fuel Reactors," Ios Alamos Scleritiflc Iaborarory Report IA-4294 (TID-4500) (June 1970).

24. Felix T. Adler, Internal Ios Alanos selentiflc Laboratong memoranda (1971).

25. Ios Alamos Program Status - Weapons Research and Devejopments Quarterly (supporting Research in Physics - Intense Neutron sources).

DIR-2103 (S RD) JuIy-september 1967, pp . 23-27 DIR-2111 (s RD) October-December 1967, $\mathrm{pg}, 17-18$ DIR-2121, Pt. I (Uncl.) Jamuary-tarch 1968, pp. 19-20

DIR-2132, Pt. I (Uncl.) April-June 1968, pp. $17-19$

DIR-2141, Pt. I (Unel.) July-September 1968, To. $18-20$

DIR-2155, Pt. I (Uncl.) October-December 1968, p. 22

DIR 2lT1, Pt. I (Uncl.) January Harch 1969, P. 24 DIR-2179, Pt. I (Unc1.) Apr11-June 1969, pp. 28-30 DIR-2I87 (S RD) July-September 1969, pp • 69-70 DIR-2195 (s RD) October-December 1969, pp. 84-85 DIR-2203 (S RD) January + DIR-2212 (S RD) Apr11-June 1970, Mp. 85-87 DII-2230 (s RD) JuIy-September I970, p. 40 IA-4614 (S RD) October-December 1970, Fp. 48-50

26. L. D. P. King, "IIquid Jet super Flux Reactor," Trans. Am. Muci. san. 11, 351 (1968).

R. I. Brasier, I. D. P. King and C. B. Mills, "Appilication of Ion Critical Mass Studies to Reactor Design," muclear Applications 6 , 266-273 (Apr11 1969).

27. B. J. Thamer, T. Wimett, R. White, and J. Hayden, Intercal IOs Alamos Sclentiflc Laboratory reports and memoranda (1967-1971).

28. T. Wimett and R. White, "Kinglet safety Fraluation Report," IOS Alamos Sclentiflc Laboratory (Varch 30, 1971). 
As pointed out in the proposal, weutrons have a unique analytic and diagnostic quality for studying the properties of matter not accessible with probes Iike $x$ rays, infrared, or microwaves.

The full potential of these unigute properties of thermal neutrons in particular can be determined only by more intense sources than those presently avatlable.

A KU: reactor at a steady-state power level of 25 wh is expected to provide central umperturbed thermal pluxes of 6 to $7 \times 10^{15}$ neutrons/ $\mathrm{cm}^{2} / \mathrm{sec}$. short-term operation with fluxes as much as a factor of $10 \mathrm{higher}$ than this should be attalnable during the exploration of the sull flux potentlal of this type of ractor.

Such Pluxes would provide IAST with a facility substantially better than the best in the world and some two orders of magnitude higher than most research reactors including the IAST WWR.

such intense neutron beams and irradiation fecilities would be important to the IAST veapons supporting reseerch effort in chemictry, metallurey, and Physics. Higher neutron Pluxes are also of drect interest to the IASL weapons program in a mamber of wajs.

The radiochemical methods of quantitativs anaiysis of nuclear weapons debris are basic to both the develownent and diegnosties of such de= vices. The sensitivity of these methods is in direct proportion to the Intensity of an available neution source. There are several instances, for exacple, where second and higher order neutron capture cross sections are of importence and can be measured only in higher neutron fluxes than are presently available. An examplo of cross gections

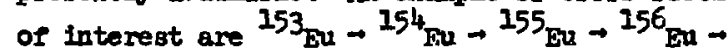
$157_{\text {Eu. }}$

Higher Intensity neutron beems can be used to asiist in the study of wespons valnerability problems.
The capaillity for produelng numerous tranguranlc elevents is of interest to the long range weapons program. An Increase in Plux 1s particulariy veluable for the production of nuclides where short Ifred Intemediertes are involved in the capture chain such es in the production of ${ }^{250} \mathrm{~cm}$ and $25 T_{\mathrm{Fm}}$. Both ${ }^{250}$ can and $25 T_{\text {Fm would be extremely valuable }}$ for use as targets for making new neutron-rich 1sotopes of the very heavy elements by heary lon bombariment. Studies of ${ }^{25 T_{\text {Fn }}}$ 1tgelf are also of prime importance since initial atuales show a much higher degree of mass symetry and a higher totel kinetic energy than previously observed in spontancous fls. 610n. The avallabllity of larger quantitles of

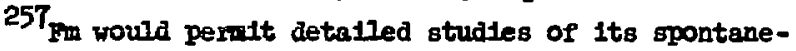
ous flesion, incluaing the varletion in weutron emission from the frogments as a function of wass and energy, the determination of $z$ as well as $A$ for the fragments, and radiochemical measurements of the frament mass $y$ lelds.

A high-flux, steady-state reactor wovld play an important role in a proposed expansion in the research, development, and application program in neutron redlograpiny at IASL. Speciflcally, such a reactor would serve as the neutron source for the following agplicetions.

1. A production thermal neutron radiogrephic fecllity for the foiloring programs:

a. Qunlity control of IASL-destoned pyrotechnics manufactured by other laboratories could be established and monitored.

b. The determination of high explosive density variations in HE firling systems could be uade.

c. Heat pipe performance can be analyzed.

d. Irradiated fuel may be radiographed.

2 . The developwent of resonance neutron radiographic techniques using bean telloring for the Inspection of Individual lominates of re-entry rehtcles. 
3. Experimentation in defining neutron radiograpisic standards and the development of theoretical systems models.

4. The development of advanced neutron imaging systems to be used in the cold, thermal, and resonance neutron energy regions.

5. Production Instrumental analyses are nor made of couponents and compounda germane to the weapons program. One of several techniques used is that of sctivation analysis. The proposed reactor fluxes vould permit high sensitivity determinstion to be made with axtreme accuracy.

If the KOWG reactor is designed to optimize the flosion spectrum in the central flux trap by replacIng the vater with a peripheral neutron corverter, It can also provide a source of degraded flssion spectrum neutrons of the order of $10^{15}$ to $10^{16}$ neutrons/ $\mathrm{cm}^{2}$-sec so that multiple neution capture processes of interest in our veapons diagnostis program could be stualed. Some examples of interest

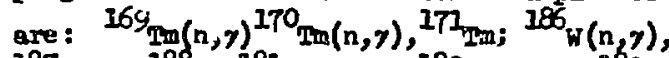

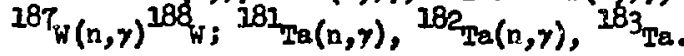
Determination of the capture cross sections for $238_{\mathrm{v}}$ In such a "fest" flux by analysis of the plutonium nuclides ultimetely formed would also be $\sigma_{\text {s }}$ interest.

Studies of flesion product ytelds from various flssile materiols could be carried out with such an Intense source of fission spectrum neutrons. The high intenalty becomes particuiarly raluable in studies of short-lived Fssion products and where only Iimited anounts of the flssile material (for example, ${ }^{242 \mathrm{Am}},{ }^{248} \mathrm{Cm}, 250 \mathrm{Cr}$ ) are available. The presently aratiable cricical assemblies at Ios Alamos are unique in being able to prortde flssion spectrum peutrons, but at mich lover intensity levels ( $\approx 10^{11}$ neutrons $/ \mathrm{cm}^{2}-\mathrm{sec}$ ) which are not sufficlent for many of these studies. 